\title{
O "ENTRE-LUGAR" DO DISCURSO DE SILVIANO SANTIAGO: UMA CONVERSA SOBRE LITERTURA E CULTURA COM O MESTRE
}

\author{
Silviano Santiago \\ Doutor Honoris Causa pela Universidad Tres de Febrero (Argentina) \\ Doutor Honoris Causa em Literatura pela Universidad de Chile (Chile) \\ Pós-doutor pela Universidade de Colônia (Alemanha)
}

Entrevistado por:

Andréia Queila Santos Gomury Mestra em Letras - Literatura Brasileira - pela Universidade do Estado do Rio de Janeiro (UERJ) agomury@gmail.com

Thallita Mayra Soares Fernandes Doutoranda em Letras - Teoria da Literatura e Literatura Comparada - pela Universidade do Estado do Rio de Janeiro (UERJ) thallitamsf@hotmail.com

Thiago Wallace Lopes Mestrando em Letras - Língua Portuguesa - pela Universidade do Estado do Rio de Janeiro (UERJ) Thiagodossantos16@gmail.com

Silviano Santiago (1936-) é escritor, ensaísta, contista, romancista e professor emérito da Universidade Federal Fluminense (UFF). Doutor em Letras pela Université de Paris (Sorbonne), foi professor da Pontifícia Universidade Católica do Rio de Janeiro (PUC-RJ) no período de 1974 a 1988 e da UFF entre 1988 e 1997. Atou como professor visitante e professor pesquisador em diversas instituições norte-americanas, como Rutgers University, University of New York at Buffalo, Stanford University, University of Texas, Indiana University, Yale University, Princeton University e University of Toronto. É, ainda, doctor honoris causa pelas Universidad Metropolitana de Ciencias de la Educación, do Chile (2013) e Universidad Tres de Febrero, Argentina (2014). Tendo atuado em grandes jornais brasileiros, é um dos mais importantes críticos literários e culturais do país, com uma obra que transita pelos mais variados gêneros, incluindo diversas coletâneas de ensaios, como Vale quanto pesa (1982) e Nas malhas da letra (1989), e ficções de sucesso, como Em liberdade (1981), Stella Manhattan (1985) e Mil Rosas Roubadas (2014), que Ihe renderam honrarias como o Prémio Iberoamericano de Letras José Donoso (2014), o Prémio Oceanos (2015) e o Prêmio Jabuti (2017). Sua escrita é rodeada de temas e questões constantes, abordados a partir de enfoques diversificados: reflexões filosóficas e propostas político-culturais se desdobram em criação artística. É uma relação presente em "O entre-lugar do discurso latino-americano", um dos seus mais proeminentes ensaios (incluído em Uma literatura nos trópicos, de 1978) , cujas ideias nortearam esta entrevista, gentilmente cedida pelo autor. 


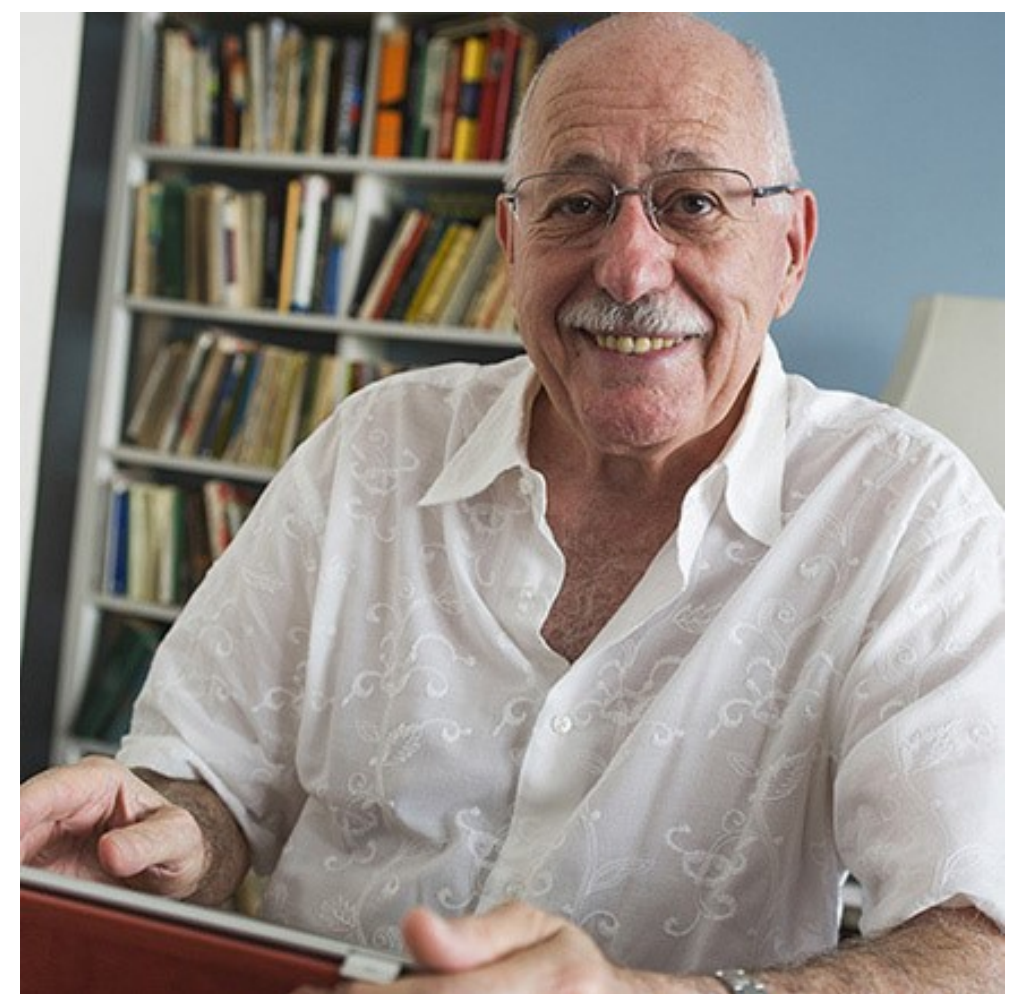

Fonte: Disponível em: <https://espantalhosdesamparados.wordpress.com/tag/silviano-santiago/>. Acesso em: 15 jul. 2019.

\section{PALIMPSESTO}

1) O trabalho de um pesquisador, por vezes, é longo e solitário, mas também é gratificante. Desse ponto de vista, como o senhor chegou ao conceito de entre-lugar? Como foi o processo para alcançar sua definição?

\section{SILVIANO SANTIAGO}

Simplificando, mas sem abusar da simplificação, direi que chego à ferramenta-deanálise (prefiro a expressão a conceito) de entre-lugar no momento em que me dou conta de que datar o começo da literatura brasileira no século 18 abre duas trincheiras. A primeira e mais evidente é que o historiador optou pelas luzes da jovem nação e do Romantismo, negando direito de fala à escuridão do período colonial. Flashback. A segunda, e 
menos evidente, é que, no caso do Brasil pós-colonial, o importante é dar-se conta de que a literatura é apenas parte da cultura. Flash-forward. Na análise das artes e, em particular, da Literatura, os princípios estéticos radicais têm de ser harmonizar com os valores culturais. Literatura é e não é. Os conceitos de texto, de metáfora, de expressão em língua portuguesa se impõem às categorias clássicas de genre (romance, poema, conto, etc.). O impasse perdurou com a análise de Haroldo de Campos da poesia de Gregório de Matos como "barroca". Os princípios estéticos levam na enxurrada os valores culturais que se depreendem da escuridão colonial. Emprestar luzes à colônia pode ser outra forma de equívoco.

\section{PALIMPSESTO}

2) Novos conceitos, em qualquer campo de estudo, podem modificar outras teorias dos estudos em literatura. Como o conceito de entre-lugar afetou os Estudos Literários?

\section{SILVIANO SANTIAGO}

Comecei a responder à pergunta pela simplificação anterior. No caso específico dos Estudos Literários, certa tradição teórica que acentuava a literariedade (literaturnost, em russo) e tem início no formalismo russo (primeiras décadas do século XX) e se prolonga até o new-criticism e o estruturalismo formal (anos 1950/1960), tem de ser obrigatoriamente revista. Ao mesmo tempo, certa tradição das Histórias literárias que acentuava a análise das obras pela perspectiva do gender em que elas se inscrevem é levada a abrir espaço para textos que se lhe escapam, como memórias, autobiografias, cartas, sermões, 
rascunhos, etc. E, finalmente, a perda da autonomia por genre engendra a entrada das questões relativas a gender - com permissão para o jogo de palavras atualérrimo.

\section{PALIMPSESTO}

3) Comparando o momento em que o senhor desenvolveu o conceito de entre-lugar e o atual cenário brasileiro, acadêmico e político, que diferenças o senhor destacaria em relação à influência e ao impacto desse conceito nos estudos literários da época e nos de hoje?

\section{SILVIANO SANTIAGO}

O impacto se dá menos no plano da literatura (e das artes) do que no plano filosófico. Nietzsche e a dupla afirmação entram no pedaço via Gilles Deleuze e se confirma a importância das filosofias da diferença. Para dar um exemplo da diferença enquanto conceito operacional, ela é ainda hoje - em nação pós-colonial que se notabiliza pela tradição da busca da identidade única, o mulato, e não da diferença racial e suas implicações de ordem pessoal e sociopolítica - algo de extremamente polêmico. Dando continuidade ao exemplo operacional: o lugar de fala, só enunciável dentro da teoria do entre-lugar, é dos tópicos mais incendiários da atualidade brasileira. Conceição Evaristo tem também razão em explicar sua obra literária pelo desempenho propriamente autoral.

\section{PALIMPSESTO}


4) 0 pesquisador é movido por um instinto que o impele a buscar por inovações que contribuam para seu campo de pesquisa. A seu ver, como surge a necessidade de criar novos conceitos?

\section{SILVIANO SANTIAGO}

Não sei até onde a necessidade teórica vem da descoberta de novos objetos, ou até onde a existência de novos objetos depende da criação teórica. Quem vem primeiro, o ovo ou a galinha? - indagou Clarice Lispector.

\section{PALIMPSESTO}

5) Ainda pensando nesse instinto por inovação que o pesquisador carrega em si: o senhor diria que a criação de novos conceitos ou releituras são sempre necessárias?

\section{SILVIANO SANTIAGO}

Novo impasse. Teria o homem nascido para criar ou para obedecer à ordem divina? Prefiro a Constituição como documento de governo do que a Bíblia sagrada. Há pessoas, como o atual presidente do Brasil, que preferem a Bíblia. Cada um com as suas ferramentas do saber. Umas convém ao movimento, à criação e à inovação; outras à obediência cega, à estagnação e ao marasmo civilizacional. E assim por diante.

\section{PALIMPSESTO}


6) Olhando de uma forma mais ampla para a literatura, qual a importância da apropriação de novos conceitos no contexto escolar e no cotidiano? Que métodos ou dicas o senhor considera úteis para se realizar esse objetivo?

\section{SILVIANO SANTIAGO}

Nada mais ideal para o aprimoramento do saber que o laboratório da sala de aula e a leitura (em casa ou na biblioteca). Tomar a experiência da sala de aula como algo em aberto e democrático, em que a fala do professor não é naturalmente a divisora de águas entre docente e aluno. Recomendaria a leitura do livro Jean-François Lyotard A condição pós-moderna (existe tradução ao português), em particular os capítulos em que fala da interioridade do saber (ensino centralizado no professor) e a exterioridade do saber (ensino pós-moderno). O saber deixa de ser considerado como um todo a ser pouco a pouco interiorizado pelo aluno e se transforma em fontes diversas e inesgotáveis de informação (como um museu de arte, uma biblioteca, etc.) que são trabalhadas por todo e qualquer aluno/pesquisador, em obediência ou desobediência aos ensinamentos do professor e da disciplina. O bom ou mau resultado depende do grau de autonomia exigido/conquistado pelo aluno.

\section{PALIMPSESTO}

7) A vida acadêmica, por diversas razões, sofre com muitas intercorrências que são alheias à vontade do pesquisador. Em meio a essas situações, que fatores o senhor considera como de impedimento para a aplicação e ampliação dos novos conceitos? 


\section{SILVIANO SANTIAGO}

Nenhuma e todas intercorrências. De novo, depende.

\section{PALIMPSESTO}

8) Um mestre sempre tem algo para transmitir a seus discípulos e muitos jovens pesquisadores tomam o senhor como um exemplo. Assim, que conselhos daria a jovens pesquisadores que têm a ambição de romper barreiras conceituais na academia?

\section{SILVIANO SANTIAGO}

Aceito a carapuça da transmissão-de-saber se me tomar como um entre muitos exemplos. Aceito-a ainda se tomar o conjunto das respostas a essa entrevista como como um entre muitos conjuntos. Nunca procurei ser docente a dar vida ao discente. Sempre incentivei o pesquisador que existe em cada aprendiz. Como disse Joaquim Pedro num dos seus filmes: "Cada um por si e Deus contra todos". Essa é a nossa luta. O saber tem mais a ver com o pacto com o Diabo, isso na dúvida de Ele existir ou não, como em Guimarães Rosa e nas palavras do compadre meu Quelemém. 


\section{THE "SPACE IN-BETWEEN" OF SILVIANO SANTI- AGO: A CONVERSATION ABOUT LITERATURE AND CULTURE WITH THE PROFESSOR}

Translated by:

Thales Sant'Ana Ferreira Mendes MA student in Brazilian Literature (Universidade do Estado do Rio de Janeiro, UERJ) thales.sanfer@hotmail.com

Silviano Santiago (1936-) is a writer, essayist, novelist and emeritus professor at the Fluminense Federal University (UFF). PhD in Letters from University of Paris (Sorbonne), he was a professor at the Pontifícia Universidade Católica do Rio de Janeiro (PUCRJ) from 1974 to 1988 and at Universidade Federal Fluminese (UFF) between 1988 and 1997. He is also an honorary doctor from the Metropolitan University of Science of Education of Chile (2013) and the University of Febrero, Argentina (2014). He has been a visiting professor and research professor in several North-American universities, such as Rutgers University, New York University at Buffalo, Stanford University, University of Texas, Indiana University, Yale University, Princeton University, and University of Toronto. Having worked in major Brazilian newspapers, he is one of the most important literary and cultural critics of the country, with a work that goes through the most varied genres. It includes various collections of essays, such as Vale quanto pesa (1982) and (1989), and blockbuster fictions, such as Em liberdade (1981), Stella Manhattan (1985) and Mil rosas roubadas (2014), which have earned him honors like the José Donoso Ibero-American Letter Prize (2014), the Oceans Prize (2015) and the Jabuti Award (2017). Constant themes and questions surround his writing: philosophical reflections and political-cultural proposals unfold in artistic creation. It is a relationship present in "O entre-lugar do discurso latino-americano" ("The Latin-American Literature: the space in-between"), one of his most prominent essays (included in Uma literatura nos trópicos, 1978), whose ideas guided this interview, kindly provided by the author. 


\section{PALIMPSESTO}

1) The work of a researcher is sometimes long and lonely, but it is also rewarding. From this point of view, how did you come to the concept of entre-lugar ["space inbetween"]? How was the process to reach its definition?

\section{SILVIANO SANTIAGO}

Simplifying, but without abusing simplification, I can say that I come to the analysis tool (I prefer the expression instead of "concept") of entre-lugar at the moment I realize that dating the beginning of Brazilian literature in the 18th century opens two trenches. The first and most obvious is that the historian has opted for the lights of the young nation and Romanticism, denying the right of speech of the colonial period's darkness. Flashback. The second, and less obvious, is that, in the case of postcolonial Brazil, it is important to realize that literature is only part of culture. Flash-forward. In the analysis of the arts, and in particular of literature, radical aesthetic principles must be harmonized with cultural values. Literature is and is not. The concepts of text, metaphor, and expression in Portuguese language impose themselves on the classical genre categories (novel, poem, short story, etc.). The deadlock has endured with Haroldo de Campos' analysis of Gregório de Matos' poetry as "baroque". Aesthetic principles bring in the flood the cultural values that derive from the colonial darkness. Lending lights to the colony may be another form of misunderstanding.

\section{PALIMPSESTO}


2) New concepts, in any field of study, may modify other theories of literature studies. How has the concept of entre-Iugar affected Literary Studies?

\section{SILVIANO SANTIAGO}

I started answering the question by the previous simplification. In the specific case of Literary Studies, a certain theoretical tradition, that accentuates literarity (literaturnost, in Russian) and begins with Russian formalism (early decades of the twentieth century) and extends to new criticism and formal structuralism (1950s and 1960s), must be reviewed. At the same time, a certain tradition of literary histories that accentuates the analysis of the works from the perspective of genre, in which they are inscribed, is led to make room for texts that escape from it, such as memories, autobiographies, letters, sermons, drafts, etc. Finally, the genre's loss of autonomy engenders the entry of gender issues - with permission for the present-day wordplay.

\section{PALIMPSESTO}

3) If you compare the moment when you have created the concept of entre-lugar and the current academic and political scene in Brazil, what differences will you highlight in relation to the influence and impact of the same concept on contemporary literary studies?

\section{SILVIANO SANTIAGO}


The impact is less at the level of literature (and the arts) than at the philosophical level. Since then, Nietzsche and the double statement appeared via Gilles Deleuze and it was confirmed the importance of the philosophies of difference. To give an example of difference as an operational concept, it is, still today - in a postcolonial nation that stands out for the tradition of the search for the unique identity, the mulatto, and not for racial difference and its personal and sociopolitical implications -, extremely controversial. Continuing the operational example: the "place of speech", only enunciable within the theory of entre-lugar, is nowadays one of the most incendiary topics in Brazilian. Conceição Evaristo is also right in explaining her literary work depending on the authorial performance.

\section{PALIMPSESTO}

4) The researcher is driven by an instinct that impels him to search for innovations that contribute to his area of research. How do you think the need to create new concepts arises?

\section{SILVIANO SANTIAGO}

I do not know how far the theoretical need comes from the discovery of new objects, or how far the existence of new objects depends on theoretical creation. Which came first, the chicken or the egg?, asked Clarice Lispector.

\section{PALIMPSESTO}


5) Still thinking about this instinct for innovation that the researcher carries within himself: would you say that the creation of new concepts and rereading are always necessary?

\section{SILVIANO SANTIAGO}

New deadlock. Was man born to create or to obey the divine order? I prefer the Constitution as a governing document instead of the Holy Bible. There are people, like the current president of Brazil, who prefer the Bible. Each person chooses his or her knowledge tools. Some of them befit movement, creation and innovation; other ones, blind obedience, stagnation and civilizational doldrums. And so on.

\section{PALIMPSESTO}

6) Looking at the literature broadly, how important is the appropriation of new concepts in the school context and in daily life? What methods or tips do you find helpful in achieving this goal?

\section{SILVIANO SANTIAGO}

Nothing is more adequate for improving knowledge than the classroom as a lab and reading (at home or in the library). Taking the classroom experience as open and democratic, where the teacher's speech is not naturally the watershed between teacher and student. I would recommend the reading of The postmodern condition, by Lyotard, specially the chapters about the interiority of knowledge (teaching focused on the teach- 
er) and the exteriority of knowledge (postmodern teaching). Knowledge is no longer considered as a whole that must be gradually internalized by the student. It becomes diverse and inexhaustible sources of information (such as an art museum, a library, etc.) that are worked on by everyone and every student or researcher. Good and bad results depend on the degree of autonomy required or achieved by the student.

\section{PALIMPSESTO}

7) Academic life, for various reasons, suffers from many complications that are unrelated to the wishes of the researcher. In the midst of these situations, what factors do you consider an impediment to the application and expansion of new concepts?

\section{SILVIANO SANTIAGO}

None of them and, at the same time, all of them. Once again, it depends.

\section{PALIMPSESTO}

8) A teacher always has something to pass on to his disciples, and many young researchers take you as an example. So what advice would you give young researchers who have the ambition to break conceptual barriers in academia?

\section{SILVIANO SANTIAGO}

I accept the responsibility of the transmission of knowing if you take me as one of many examples. I still accept it if I take the set of answers in this interview as one among 
many other sets. I have never tried to be a teacher who makes the student a student. I have always encouraged the researcher in each learner. As Joaquim Pedro once has said in one of his films: "One for himself and God against all". This is our fight. Knowledge has more to do with the pact with the Devil, in the doubt of whether he exists or not, as in Guimarães Rosa and in the words of Quelemém. 